\title{
Arbuscular mycorrhizal assemblages along contrasting Andean forests of Southern Chile
}

\author{
César Marín ${ }^{1 *}$, Paula Aguilera ${ }^{2}$, Pablo Cornejo ${ }^{2}$, Roberto Godoy ${ }^{1}$, Fritz Oehl ${ }^{3,4}$, Götz \\ Palfner $^{5}$, Jens Boy ${ }^{6}$
}

${ }^{1}$ Instituto de Ciencias Ambientales y Evolutivas, Universidad Austral de Chile, 5090000 Valdivia, Chile. Corresponding author: cesar.marin@postgrado.uach.cl

${ }^{2}$ Center of Amelioration and Sustainability of Volcanic Soils. BIOREN-UFRO, Universidad de La Frontera, P.O. Box 54-D, 4780000 Temuco, Chile. ${ }^{3}$ Agroscope, Institute of Sustainability Sciences, Reckenholzstrasse 191, 8046 Zürich, Switzerland. ${ }^{4}$ Departamento de Micologia, CCB, Universidade Federal de Pernambuco, Av. da Engenharia s/n, Cidade Universitária, 50740-600,2611606 Recife, PE,Brazil. ${ }^{5}$ Departamento de Botánica, Universidad de Concepción, Barrio Universitario s/n, 4030000 Concepción, Chile. ${ }^{6}$ Institute of Soil Science, Leibniz Universität Hannover, Herrenhäuser Str. 2, 30419 Hannover, Germany.

\begin{abstract}
Southern Chilean pristine temperate rainforests have been floristically stable during the Holocene, thus representing a pre-industrial baseline of forest ecology. Given this and its edaphic limitations, it is imperative to better understand these forests ecological patterns of mycorrhizal symbiosis. Therefore, here we compare the arbuscular mycorrhizal (AM) communities in three treeline Nothofagus pumilio contrasting plots of Chilean Andes (a volcano crater, pristine forest, and disturbed forest). The AM community assemblages were determined by morphological identification and spore counting, in three A horizon soil samples by plot. In the same nine soil samples, standard chemical analysis was performed. Eighteen AM species were described; Acaulospora was the most abundant genus. The forest plot had the highest AM species richness compared to the disturbed and crater plots. Interestingly, soils Olsen $\mathrm{P}$ (plant available phosphorus), $\mathrm{pH}$, and $\mathrm{Al}+++$ saturation similarly affected the AM assemblages. We suggest that some AM species could be specially adapted to extremely high $\mathrm{Al}$ saturation and extremely low plant available P conditions, as those experienced on Andean Nothofagus forests. These species may help initiate biological succession on highly disturbed ecosystems. We suggest that mycorrhizal fungi play a key role in seedling colonization of extreme environments such as the Andean treeline.
\end{abstract}

Keywords: Al-saturation, arbuscular mycorrhizal fungi, Nothofagus pumilio, plant available P, succession, temperate rainforests 


\section{Introduction}

Old-growth temperate rainforests in mountainous areas of Southern South America account for more than half of the southern hemisphere's temperate rainforests (Armesto et al., 2010), and are interesting model ecosystems because atmospheric pollution in these ecosystems is extremely low and because the floristic composition of these forests has been stable throughout the Holocene (Armesto et al., 2010). This is reflected in the rainfall chemistry of these areas, which is similar to that of preindustrial conditions (Oyarzún et al., 2004). Physiologically, temperature is the main environmental factor that influences the integrity and function of these forests. Thus, these ecosystems are highly sensitive to climatic variability and anthropogenically induced alterations to biogeochemical cycles, especially at the forest limit at high altitudes. Subsequently, these forests are ideal systems to test global change hypotheses regarding tolerance to rising temperature and rising atmospheric carbon dioxide (Álvarez et al., 2015). At the forest limit, dendrochronological studies of the broadly distributed angiosperm $\left(33^{\circ} \mathrm{S}\right.$ to $\left.55^{\circ} \mathrm{S}\right)$ Nothofagus pumilio (P. et E.) Krasser have indicated a recent increase in temperature (Álvarez et al., 2015).

These forests, surrounded by arid ecosystems, constitute a nutrient-limited biogeographic island of high endemism (Armesto et al., 2010). The biogeochemistry of these forests is characterized by low inputs of atmospheric inorganic N (Oyarzún et al., 2004), though long-distance atmospheric inputs (aerosols, diluted marine salts) have influenced the biogeochemistry and ecosystem regulation of these forests (Álvarez et al., 2015). In addition to limited inputs of atmospheric nutrients, Chilean temperate rainforests are also nutrient limited due to edaphic conditions such as high weathering rates. The soil of these Andean temperate rainforests (Andisols) originates from volcanic ash and is characterized by low inorganic N (Oyarzún et al., 2004) and high total $\mathrm{P}$ content, though plant available $\mathrm{P}$ is low (Borie et al., 2010). Additionally, the soil of these forests is subject to extreme temperature due to the wide daily temperature range of these ecosystems, and due to less snow cover and earlier snow melting caused by recent warming (colder winters in a warmer climate; Briceño et al., 2014). In Andisols, allophanes retain soil organic matter (SOM) thus slowing decomposition and, in turn, slowing Carbon (C), nitrogen (N), and phosphorus (P) cycling (Matus et al., 2009; 2014). The high C, N, and total $\mathrm{P}$ (but low $\mathrm{C}$ turnover rates) of Andisols are explained by high levels of SOM stabilization (Matus et al., 2014). Under these biotic and abiotic restrictions, functional compensatory strategies have evolved in temperate rainforests.

Among the most important strategies to cope with low nutrient availability are symbiotic mycorrhizal associations (Castillo et al., 2006; Etcheverría et al., 2009; Borie et al., 2010; Azcón-Aguilar and Barea, 2015). Specifically, Turner (2008) hypothesizes that soil phosphorus is a resource partitioned by plants, due to the action of specialized co-existing mycorrhizal associations, and that this partition would explain plants co-existence. This hypothesis could help to explain the composition changes of associated mycorrhizal fungi. It should be noted, however, that because arbuscular mycorrhizae have low host specificity, fungal community changes are not only affected by plant community changes (Davison et al., 2015). Turner (2008) adds that this soil phosphorus partition would be especially predominant in soils with low P availability, such as in South American temperate rainforests. 
Thus, plant and mycorrhizal community composition changes would be expected as a result of changing available $P$.

Besides P limitation, Southern Chilean temperate rainforest soils are characterized by extremely high levels of Al toxicity (Al saturation; Aguilera et al., 2014). Via various mechanisms, mycorrhizal fungal species can protect host plants against Aluminum (Al) phytotoxicity (Aguilera et al., 2014; Seguel et al., 2016). Mycorrhizal species present in a community subjected to high levels of Al toxicity would be drastically different from those found in non-Al toxic soils (Aguilera et al., 2014; Seguel et al., 2016). Some arbuscular mycorrhizal (AM) fungi associated with specific hosts have been shown to significantly promote plant growth and fitness in acidic soils with high Al phytotoxicity (Borie et al., 2010; Aguilera et al., 2014; Seguel et al., 2016). Even at high Al toxicity levels, slight changes in Al saturation have been shown to change the arbuscular mycorrhizal community composition (Borie et al., 2010). Also, differences in host-plant tolerance to Al has been shown to alter arbuscular mycorrhizal communities (Aguilera et al., 2014).

There are several potential explanations for how high Al in soils might affect fungal community composition. It can be argued that plants with mycorrhizal associations use different photoassimilation pathways when soil $\mathrm{Al}$ is high (Borie et al., 2010; Aguilera et al., 2014). When available P is extremely low and soil $\mathrm{Al}$ is extremely high, mycorrhizal fungi would be of great importance to plant growth, as the fungal functional specialization and efficiency greatly affects plant fitness (Aguilera et al., 2014). Thus, in soils with naturally low-P and high-Al, adapted fungi and rhizosphere would magnify the known growth benefits of mycorrhizal fungi to plants.
Forests of Southern Chile mainly have ectomycorrhizal (EM) associations. For example, Nothofagus spp. forests (Valenzuela et al., 1999) host a high proportion of Agaricales, while Valdivian and native coniferous forests harbor mainly arbuscular mycorrhizae (Godoy and Mayr, 1989; Carrillo et al., 1992; Godoy et al., 1994; Castillo et al., 2006; Oehl et al., 2012; Medina et al., 2015; Castillo et al., 2016). In EM or AM dominated forests, the presence of the other mycorrhizal types (either EM or AM) is not excluded, as they are only in lower proportions and are often associated with understory plants. Mycorrhizal associations seem to be fundamental to the region's biogeochemistry, as shown by Etcheverría et al. (2009), who demonstrated that AM fungi play a major role in $\mathrm{C}, \mathrm{N}$, and SOM biogeochemical cycles in the volcanic soils of Chilean temperate rainforests.

The effects of climate change are especially harsh on mountain ecosystems, as these ecosystems are highly vulnerable (Álvarez et al., 2015). Microclimatic and edaphic factors are predicted to have an important effect on plant aboveground assemblages and distribution. Thus, due to volcanic events in Southern Chile, a large amount of climatic and geological changes have occurred in the region (Armesto et al., 2010). There are several ways in which stability can be reached in nutrient-limited ecosystems. While mycorrhizal associations are globally distributed, they are especially important in Southern temperate rainforests, as a higher than average proportion of vascular plants present mycorrhizal symbiosis (Soudzilovskaia et al., 2015). Highly porous, nutrient poor volcanic soils are common in mountainous Southern Chilean temperate rainforests (Etcheverría et al., 2009; Borie et $a l ., 2010)$. Thus, the greater occurrence of mycorrhizae (Soudzilovskaia et al., 2015) in these forests compared to other ecosystems could be explained 
by the importance of mycorrhizal associations in biogeochemical cycles.

Several edaphic variables (plant available P, C, $\mathrm{N}, \mathrm{Ca}$ and $\mathrm{pH}$ ) as well as vegetation patterns are among the main factors that structure soil fungal assemblages (Tedersoo et al., 2014), and specifically, arbuscular mycorrhizal assemblages (Davison et al., 2015). Several molecular studies of soil fungal communities in northern Patagonia focus on EM fungi in Chilean and Argentinian Nothofagusforests (Nouhra et al., 2013). Furthermore, recent studies at the global scale have also documented all fungal guilds (Tedersoo et al., 2014) and specific AM assemblages (Davison et al., 2015) in Chilean and Argentinian native coniferous forests. Despite the well-documented role of mycorrhizal fungi in ecosystems, the diversity patterns, symbiotic associations, edaphic controls, and assemblages of these organisms have been poorly studied in northern Patagonia temperate rainforests.

We hypothesize that the mycorrhizal species composition of temperate rainforests reflects the ecophysiological needs imposed by the Andisol substratum, namely low P availability and high Al toxicity. Furthermore, we hypothesize that within high-Al soils, as treeline temperate Andean rainforestes, AM diversity increases with higher Al saturation, as detoxifying specialists are increasingly needed. Lastly, we predict that within extremely low plant available P soils, AM diversity increases with decreasing soil $\mathrm{P}$ availability. The latter would require more diverse communities in order to exploit harder to access $\mathrm{P}$ such as that found in organo-mineral complexes or organic P. In order to test these hypotheses we performed a baseline study carried out in Puyehue National Park in Southern Chile. We aimed at determining the AM fungal assemblages in contrasting
Nothofagus pumilio plots in the Andes of southern Chile (a volcano crater, pristine forest, and disturbed forest).

\section{Materials and Methods}

\subsection{Study plots}

We selected three $30 \times 30 \mathrm{~m}$ plots in the Andes Mountains of Southern Chile in Puyehue National Park $\left(40^{\circ} 47^{\prime} \mathrm{S}-72^{\circ} 12^{\prime} \mathrm{O}\right)$. The first plot (from here on referred to as "forest") was located within the altitudinal limit $(1,150$ - 1,200 m.a.s.1.) of a pristine, deciduous temperate forest of Nothofaguspumilio. The second plot (referred to as "crater"), which represents a successional forest, was located inside the Casablanca volcano crater (Raihuen crater) at 1,273 m.a.s.1. The crater plot is dominated by Baccharisnivalis Schultz Bip., Seneciobipontinii Wedd., Pernettya pumila (L.F.) Hooker and Quinchamalium chilense Lam. (phytosociological background in Freiberg, 1985). Located at 1,050 m.a.s.1., the third plot (referred to as "disturbed") was located in a $N$. pumilio forest crossed by a gravel road. The samples from this third plot were taken at a short distance $(<3 \mathrm{~m})$ from the road (the road crossed the disturbed plot). This third plot was highly disturbed by erosion and constant deposition of gravel. All plots receive more than $7,000 \mathrm{~mm}$ of annual precipitation, mostly during winter (June to September), and the annual mean temperature is $4.5^{\circ} \mathrm{C}$ (Oyarzún et al., 2004). During the Pleistocene, the plots were covered by glaciers. The deposition of Andesitic-Basaltic ashes caused by constant volcanic activity in the region has been a main input to the soil, which is classified as Andisol (Typic Dystrandepts; Soil Survey Staff, 1999). 


\subsection{Soil sampling}

To identify AM fungi species assemblages and determine soil chemistry, bulk soil samples were taken in the three plots (forest, crater, and disturbed). In three randomly selected sites in each plot, one $1,000 \mathrm{~g}$ soil sample was taken (A horizon, approx. $20 \mathrm{~cm}$ x $20 \mathrm{~cm}$ x $20 \mathrm{~cm}$; nine sample sites in total). After removing the $\mathrm{O}$ horizon, roots were carefully removed and the samples were thoroughly mixed. Special attention was given to the roots removal on the forest and disturbed plots, as these were dominated by Nothofagus species, which roots are associated with ectomycorrhizal fungi. By each sample, a $25 \mathrm{~g}$ soil aliquot was taken for AM fungi spore isolation and determination, and another $25 \mathrm{~g}$ soil aliquot was dried at ambient temperature and sieved to $<2 \mathrm{~mm}$ for soil chemical analysis.

\subsection{AM fungi isolation and identification}

Spores were isolated from soils using wet sieving and a sucrose density gradient (Sieverding, 1991): $25 \mathrm{~g}$ of soil were passed through three sieves $(500,125$ and $32 \mu \mathrm{m})$ and washed with distilled water. The portion collected in the $32 \mu \mathrm{m}$ mesh was combined with the fractions collected in the 500 and $125 \mu \mathrm{m}$ sieves. This combination was distributed in plastic tubes, where 25 $\mathrm{mL}$ of a $70 \%$ sugar solution was added. Samples were decanted by centrifugation for $2 \mathrm{~min}$ at $2000 \mathrm{rpm}$ and then washed and transferred to petri dishes for examination and quantification using binocular microscopes at up to 400 -fold magnification. Finally, samples were placed on slides with a polyvinyl alcohol-lactic acid glycerol (PVLG) medium. Identification of AM fungal species was carried out by observation of morphological characteristics such as spore wall structures, subtending hyphae, and germination structures (Oehl et al., 2011a; b); identification manuals were used during observations (e.g. Oehl et al., 2011a; b).

\subsection{Soil chemical analysis and characteristics of the study plots}

Soil $\mathrm{pH}$ and electrical conductivity (EC) were determined using a conductivity probe (Orion Star A329) and a $\mathrm{pH}$ meter (Orion Star A329), respectively, using a 1:2.5 solution (soil:water). The percentage of $\mathrm{C}$ in the soil was determined by colorimetric determination of the reduced chromate following dichromate acidic oxidation (Zagal and Sadzawka, 2007). The percentage of $\mathrm{N}$ was determined using titration with a Kjeldahl digestion ( $\mathrm{NH}_{3}$ distillation). The concentration of plant available $\mathrm{P}$ was determined by colorimetric methods using molybdenum blue following sodium bicarbonate extraction ( $0.5 \mathrm{M} / \mathrm{L}, \mathrm{pH} 8.5)$. Soil calcium $(\mathrm{Ca})$, magnesium $(\mathrm{Mg})$, potassium $(\mathrm{K})$, and sodium $(\mathrm{Na})$ were determined using an atomic absorption spectrophotometer (AAnalyst 400) following ammonium acetate $(1 \mathrm{M} / \mathrm{L}, \mathrm{pH}$ 7.0) and lanthanum extractions. Potassium chloride extractions (1 M/L) were performed to isolate $\mathrm{Al}$, and the final concentration of $\mathrm{Al}$ in the soil was determined by atomic absorption spectrophotometry (AAnalyst 400). Aluminum saturation (Sat_Al) was calculated as a percentage based on the formula involving the cations (Sat_Al $=(\mathrm{Al} * 100) /(\mathrm{Al}+\mathrm{Ca}+\mathrm{K}+\mathrm{Mg}+\mathrm{Na}))$.

Previous studies on the study plots have shown that the soils are coarse in texture and are composed of black-sand scoriaceous basaltic material containing allophanes (50\% of clay weight; Matus et al., 2009). Another previous study has shown that the $\mathrm{O}_{\mathrm{L}}$ horizon of the study plots has $1.5 \mathrm{~cm}$ of litter and the $\mathrm{O}_{\mathrm{h}}$ horizon is brownish and dark (Godoy and Opitz, 1998); both horizons have a large amount of fine roots (Godoy and Opitz, 1998). The A horizon has a depth of about $17 \mathrm{~cm}$ and has a strong development of fine and thick roots; the $\mathrm{AC}$ horizon has about $38 \mathrm{~cm}$ deep (Godoy and Opitz, 1998). 
Table 1. Soil chemical characteristics of the study sites and plots.

\begin{tabular}{|c|c|c|c|c|c|c|c|c|c|c|c|c|}
\hline Plot & Site & $\mathrm{pH}$ & $\mathrm{CE}(\mu \mathrm{S})$ & $\mathrm{C}(\%)$ & $\mathrm{N}(\%)$ & $\mathrm{P}(\mathrm{mg} / \mathrm{Kg})$ & $\mathrm{Ca}(\mathrm{mg} / \mathrm{Kg})$ & $\mathrm{Mg}(\mathrm{mg} / \mathrm{Kg})$ & $\mathrm{Na}(\mathrm{mg} / \mathrm{Kg})$ & $\mathrm{K}(\mathrm{mg} / \mathrm{Kg})$ & $\mathrm{Al}(\mathrm{mg} / \mathrm{Kg})$ & Sat_Al (\%) \\
\hline \multirow[t]{3}{*}{ Forest } & Sil & $5.732 \pm 0.000 \mathrm{c}$ & $70.168 \pm 0.040 \mathrm{~d}$ & $3.296 \pm 0.099 \mathrm{c}$ & $0.024 \pm 0.001 \mathrm{c}$ & $18.284 \pm 0.005 \mathrm{~d}$ & $98.578 \pm 0.146 \mathrm{a}$ & $69.824 \pm 0.052 \mathrm{c}$ & $159.616 \pm 0.073 \mathrm{c}$ & $182.234 \pm 0.089 \mathrm{~b}$ & $957.493 \pm 0.400 \mathrm{~d}$ & $65.236 \pm 0.526 \mathrm{c}$ \\
\hline & $\mathrm{Si} 2$ & $5.725 \pm 0.000 \mathrm{c}$ & $63.450 \pm 0.026 \mathrm{~d}$ & $3.127 \pm 0.066 \mathrm{~b}$ & $0.022 \pm 0.000 \mathrm{~b}$ & $17.492 \pm 0.003 \mathrm{~d}$ & $73.767 \pm 0.097 \mathrm{a}$ & $61.070 \pm 0.034 \mathrm{~b}$ & $147.240 \pm 0.049 \mathrm{~b}$ & $167.060 \pm 0.060 \mathrm{c}$ & $889.600 \pm 0.267 \mathrm{~d}$ & $66.451 \pm 0.527 \mathrm{~d}$ \\
\hline & $\mathrm{Si} 3$ & $5.718 \pm 0.000 \mathrm{~b}$ & $56.732 \pm 0.032 \mathrm{c}$ & $2.959 \pm 0.079 \mathrm{~b}$ & $0.021 \pm 0.001 \mathrm{~b}$ & $16.700 \pm 0.004 \mathrm{c}$ & $48.955 \pm 0.117 \mathrm{a}$ & $52.315 \pm 0.041 \mathrm{~b}$ & $134.864 \pm 0.058 \mathrm{~b}$ & $151.886 \pm 0.072 \mathrm{a}$ & $821.707 \pm 0.320 \mathrm{c}$ & $67.925 \pm 0.526 \mathrm{~d}$ \\
\hline \multirow[t]{3}{*}{ Crater } & $\mathrm{Si} 4$ & $5.202 \pm 0.000 \mathrm{a}$ & $29.962 \pm 0.001^{\mathrm{a}}$ & $4.846 \pm 0.235 \mathrm{~d}$ & $0.047 \pm 0.003 \mathrm{~d}$ & $16.158 \pm 0.010 \mathrm{c}$ & $311.705 \pm 0.047 \mathrm{~d}$ & $125.961 \pm 0.054 \mathrm{~d}$ & $164.090 \pm 0.021 \mathrm{~d}$ & $284.591 \pm 0.073 \mathrm{~d}$ & $818.766 \pm 0.075 \mathrm{c}$ & $48.018 \pm 0.278 \mathrm{a}$ \\
\hline & $\mathrm{Si} 5$ & $5.195 \pm 0.000 \mathrm{a}$ & $29.750 \pm 0.001^{\mathrm{a}}$ & $4.347 \pm 0.294 \mathrm{~d}$ & $0.040 \pm 0.004 \mathrm{~d}$ & $14.063 \pm 0.012 \mathrm{~b}$ & $301.767 \pm 0.059 \mathrm{~d}$ & $114.414 \pm 0.068 \mathrm{~d}$ & $159.646 \pm 0.026 \mathrm{~d}$ & $269.091 \pm 0.091 \mathrm{~d}$ & $802.833 \pm 0.094 \mathrm{~b}$ & $48.723 \pm 0.278 \mathrm{a}$ \\
\hline & Si6 & $5.188 \pm 0.000 \mathrm{a}$ & $29.538 \pm 0.001^{\mathrm{a}}$ & $3.848 \pm 0.196 \mathrm{c}$ & $0.034 \pm 0.003 \mathrm{c}$ & $11.968 \pm 0.008 \mathrm{~b}$ & $291.828 \pm 0.039 \mathrm{c}$ & $102.868 \pm 0.045 \mathrm{c}$ & $155.203 \pm 0.017 \mathrm{c}$ & $253.592 \pm 0.061 \mathrm{c}$ & $786.901 \pm 0.063 \mathrm{~b}$ & $49.478 \pm 0.280 \mathrm{a}$ \\
\hline \multirow[t]{3}{*}{ Disturbed } & $\mathrm{Si7}$ & $5.804 \pm 0.000 \mathrm{~d}$ & $31.883 \pm 0.002 \mathrm{c}$ & $1.545 \pm 0.118 \mathrm{a}$ & $0.013 \pm 0.000 \mathrm{a}$ & $8.317 \pm 0.001 \mathrm{a}$ & $217.181 \pm 0.094 \mathrm{c}$ & $14.619 \pm 0.008 \mathrm{a}$ & $41.429 \pm 0.011 \mathrm{a}$ & $186.290 \pm 0.169 \mathrm{c}$ & $452.496 \pm 0.023 \mathrm{a}$ & $49.615 \pm 0.075 \mathrm{~b}$ \\
\hline & $\mathrm{Si} 8$ & $5.755 \pm 0.000 \mathrm{~d}$ & $31.600 \pm 0.001 \mathrm{~b}$ & $1.345 \pm 0.078 \mathrm{a}$ & $0.012 \pm 0.000 \mathrm{a}$ & $8.119 \pm 0.001 \mathrm{a}$ & $201.233 \pm 0.063 \mathrm{~b}$ & $13.295 \pm 0.005 \mathrm{a}$ & $39.520 \pm 0.007 \mathrm{a}$ & $157.618 \pm 0.113 \mathrm{a}$ & $448.633 \pm 0.015 \mathrm{a}$ & $52.148 \pm 0.074 \mathrm{~b}$ \\
\hline & $\mathrm{Si} 9$ & $5.706 \pm 0.000 \mathrm{~b}$ & $31.317 \pm 0.001 \mathrm{~b}$ & $1.146 \pm 0.094 \mathrm{a}$ & $0.012 \pm 0.000 \mathrm{a}$ & $7.921 \pm 0.001 \mathrm{a}$ & $185.286 \pm 0.075 \mathrm{~b}$ & $11.970 \pm 0.006 \mathrm{a}$ & $37.611 \pm 0.009 \mathrm{a}$ & $128.945 \pm 0.135 \mathrm{a}$ & $444.770 \pm 0.018 \mathrm{a}$ & $55.006 \pm 0.074 \mathrm{c}$ \\
\hline
\end{tabular}

(a) SE indicated by \pm . Letters indicate quartiles. $\mathrm{P}=$ plant available P. (b) All the analytical techniques were done according to the Normalization and Accreditation Commission of the Chilean Soil Science Society (Zagal and Sadzawka, 2007).

\subsection{Statistical analysis}

In order to test the effectiveness of AM sampling, a species accumulation curve across pooled individuals (spore counting of AM fungi) was calculated using the function accumresult of the Biodiversity $R$ package (Kindt and Coe, 2005) in R 3.2.2 (R Development Core Team, 2015). In order to describe diversity patterns in the nine sites, several diversity indices accounting for alpha diversity, dominance, and evenness (Richness, S; Shannon, H'; Simpson, 1-D1; Inverse Simpson, D2; Evenness, J'; Berger, BP) were calculated using the function diversityresult of the Biodiversity $\mathrm{R}$ package (Kindt and Coe, 2005).

The differences between diversity indices between sites were analyzed using a one-way ANOVA in which the plot (three samples per plot) was the input variable and the index (Simpson, Shannon, Berger, etc.) was the output variable (index $\sim$ plot).

Rényi diversity profiles of each site were calculated using the function renyiresult of the Biodiversity $\mathrm{R}$ package (Kindt and Coe, 2005). Rényi diversity profile values (H-alpha) are calculated on the basis of the relative abundance of each species and a scale parameter (alpha), ranging from zero to infinity (Kindt and Coe, 2005). Rényi profiles are directly related to richness (S) and to the Shan- non $\left(\mathrm{H}^{\prime}\right)$, Simpson (D1) and Berger (BP) indices. Thus, in a Rényi profile, the $\mathrm{H}$-alpha values reflect diversity (i.e., community $\mathrm{A}$ is more diverse than community B if A is plotted above B; Kindt and Coe, 2005).

In the profile, community $\mathrm{A}$ is more diverse or has more evenness than community $\mathrm{B}$, if the former is above and never intersects with the latter.

To calculate the alpha, beta, and gamma diversity (measured as contribution to the Simpson index, 1-D1) of the plots, the function contribdiv in the $\mathrm{R}$ package vegan (Oksanen et al., 2015) was used. The function vegdist of the R package vegan (Oksanen et al., 2015) was used to calculate BrayCurtis dissimilarity, an ecological distance used to generate heat maps of the samples and species, and it was also used in a distance-based Redundancy Analysis (db-RDA). The db-RDA modeled the edaphic variables predicting the AM community structure. The variables order of the db-RDA was given by adding variables according to the Variance Inflation Factor -VIF (VIF < 10); 1,000 permutations were carried out. The db-RDA was calculated using the function capscale of the $\mathrm{R}$ package vegan (Oksanen et al., 2015). 


\section{Results}

\subsection{Soil analysis and AM fungi assemblage}

Regarding the soil analysis of this study, the disturbed plot sites were poorer in $\mathrm{Mg}$, Na, K, plant available $\mathrm{P}$ content, $\mathrm{C}$ and $\mathrm{N}$ (percentages), and they were slightly more acidic than sites of the other two plots (Table 1). However, Ca was significantly lower in the forest plot sites while $\mathrm{Al}$ saturation was close to $70 \%$. Furthermore, the forest plot had higher plant available $\mathrm{P}$ and EC. In the crater plot sites, $\mathrm{Mg}, \mathrm{Na}, \mathrm{K}$, and $\mathrm{C}$ and $\mathrm{N}$ were significantly higher. All sites were slightly acidic (pH between 5.0 and 6.0).

More than 8,000 AM fungal spores were isolated and identified in the collected soil samples (Figure 1). In total, $18 \mathrm{AM}$ fungal species were identified in the nine sites composing the three plots. These spe- cies belong to two classes, four orders, and six families: eight Acaulosporaceae species were identified, two Claroideoglomus (Entrophosporaceae) species were identified, one Glomus (Glomeraceae) species was identified, two Rhizoglomus and one Simiglomus (Glomeraceae) species were identified, one $\mathrm{Scu}$ tellospora (Scutellosporaceae) was identified, one Ambispora (Ambisporaceae) and two Archaeospora (Archaeosporaceae) species were identified. Subsequently, eight genera of the Glomeromycota (Table 2) were identified in this study according to methods by Oehl (2011a). Two AM fungal species of the Acaulospora genus could potentially be undescribed species. AM fungal species belonging to the Acaulospora genus were abundant in the highest proportion (Table 2). In general, the three sites within each given plot were similar in terms of AM fungal species composition and abundance.

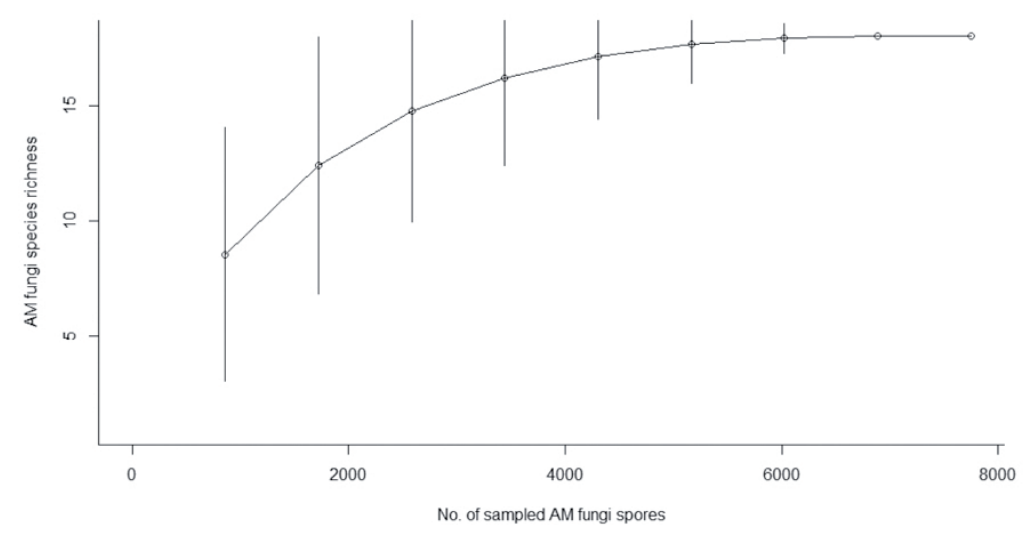

Figure 1. Species richness's accumulation curve with pooled individuals of arbuscular mycorrhizal (AM) fungi (No. of sampled AM fungi spores) for all plots and sites combined. Bars represent permutations (1000). 
Table 2. Species and relative abundance (relative to each site) of arbuscular mycorrhizal (AM) fungi in the three plots in the Andean mountain area of south-central Chile (forest, crater, disturbed) and nine sites (Si 1-Si 9).

\begin{tabular}{|c|c|c|c|c|c|c|c|c|c|c|}
\hline \multirow{2}{*}{$\begin{array}{l}\text { (a) AM class, order and } \\
\text { family }\end{array}$} & \multirow[t]{2}{*}{ AM species } & \multicolumn{3}{|c|}{ Forest } & \multicolumn{3}{|c|}{ Crater } & \multicolumn{3}{|c|}{ Disturbed } \\
\hline & & Si 1 & Si 2 & $\mathrm{Si} 3$ & $\mathrm{Si} 4$ & Si 5 & Si 6 & $\mathrm{Si} 7$ & Si 8 & $\mathrm{Si} 9$ \\
\hline \multicolumn{11}{|l|}{$\begin{array}{l}\text { Glomeromycetes } \\
\text {-Diversisporales } \\
\text {--Acaulosporaceae }\end{array}$} \\
\hline & Acaulospora alpina Oehl, Sýkorová \& Sieverd & - & $\cdot$ & - & - & - & - & - & $\cdot$ & $\therefore$ \\
\hline & Acaulospora laevis Gerd. \&Trappe & - & - & 口 & - & 마 & ㅁ & ㅁ & ㅁ & - \\
\hline & Acaulospora paulinae Blaszk. & . & . & 。 & - & - & - & - & - & - \\
\hline & $\begin{array}{l}\text { Acaulospora punctata Oehl, Palenz., Sánchez-Castro, G.A. Silva, C. Castillo \& } \\
\text { Sieverd }\end{array}$ & $\cdot$ & $\square$ & $\cdot$ & $\cdot$ & $\cdot$ & $\cdot$ & $\cdot$ & $\square$ & $\square$ \\
\hline & Acaulospora scrobiculataTrappe & . & . & 。 & - & - & - & - & - & - \\
\hline & Acaulospora sp CLI* & 。 & a & 。 & - & - & - & - & - & - \\
\hline & Acaulospora sp. CL2* & - & - & - & - & - & - & - & - & - \\
\hline & Acaulospora spinosa C. Walker \& Trappe & . & . & 。 & - & - & - & - & - & - \\
\hline \multicolumn{11}{|l|}{$\begin{array}{l}\text {-Glomerales } \\
\text {--Entrophosporaceae }\end{array}$} \\
\hline & $\begin{array}{l}\text { Claroideoglomus claroideum (N.C. Schenck\& G.S. Sm.) C. Walker \& A. } \\
\text { Schüßler }\end{array}$ & - & $\therefore$ & $\cdot$ & $\cdot$ & $\cdot$ & $\cdot$ & - & - & - \\
\hline \multirow{5}{*}{--Glomeraceae } & Claroideoglomus etunicatum (W.N. Becker \& Gerd.) C. Walker \& A. Schüßler & - & - & - & $\cdot$ & $\cdot$ & 口 & - & - & - \\
\hline & & & & & & & & & & \\
\hline & Rhizoglomus invermaium (I.R. Hall) Sieverd., G.A. Silva \& Oehl & 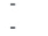 & - & 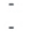 & - & $\begin{array}{l}\square \\
-\end{array}$ & $=$ & . & . & : \\
\hline & $\begin{array}{l}\text { Rhizoglomus intraradices (N.C. Schenck \& G.S. Sm.) Sieverd., G.A. Silva \& } \\
\text { Oehl }\end{array}$ & - & $\cdot$ & - & $\therefore$ & $\cdot$ & - & - & - & $\cdot$ \\
\hline & Simiglomus hoi (S.M. Berch \& Trappe) G.A. Silva, Oehl \& Sieverd. & - & - & - & $\circ$ & 。 & - & - & - & $\cdot$ \\
\hline \multicolumn{11}{|l|}{$\begin{array}{l}\text {-Gigasporales } \\
\text {--Scutello sporaceae }\end{array}$} \\
\hline & Scutellos poracalospora (T.H. Nicolson \& Gerd.) C. Walker \& F.E. Sanders & - & . & 。 & - & - & - & - & - & - \\
\hline \multicolumn{11}{|l|}{$\begin{array}{l}\text { Archaeosporomycetes } \\
\text {-Archaeosporales } \\
\text {--Ambisporaceae }\end{array}$} \\
\hline \multirow{3}{*}{--Archaeosporaceae } & Ambispora reticulata Oehl \& Sieverd. & $\square$ & $\cdot$ & ㅁ & $\cdot$ & - & - & $\cdot$ & $\cdot$ & $\cdot$ \\
\hline & $\begin{array}{l}\text { Archaeospora myriocarpa (Spain, Sieverd. \& N.C. Schenck) Oehl, G.A. Silva, } \\
\text { B.T. Goto \& Sieverd. }\end{array}$ & - & - & 。 & - & - & - & - & - & - \\
\hline & Archaeospora trappei (R.N. Ames \& Linderman) J.B. Morton \& D. Redecker & $=$ & - & . & - & - & - &. & $=$ & - \\
\hline
\end{tabular}

(a) $\square<1-5 \%, \cdot 5-15 \%, \square 15-25 \%, \square 25-50 \%, \square>50 \%,:$ non detected. (b) CL1, CL2 corresponds to undescribed AM fungi species.

\subsection{AM diversity and community structure in different ecosystems}

The $N$. pumilio forest plot had significantly higher species richness (11 -13 AM fungal species, $p<0.001$, Table 3 ) than the other plots. The species richness of the crater and disturbed plots was not significantly different (6-7 AM fungal species were identified). In addition, the alpha diversity
(Figure 2) and Shannon $\left(\mathrm{H}^{\prime}\right)$ and Simpson $\left(1-\mathrm{D}_{1}\right)$ diversity indices (Table 3 ) were significantly higher in the $N$. pumilio forest plot than in the other two plots. The alpha diversity of the crater and disturbed plots did not differ significantly. Dominance measured by the Evenness $\left(\mathrm{J}^{\prime}\right)$ and Berger (BP) indices was significantly lower in the forest sites (Table 3). Simpson's diversity index was not significantly different among the nine sites, but the $N$. pumilio forest plot sites had significantly higher alpha diversity (Table 3). 


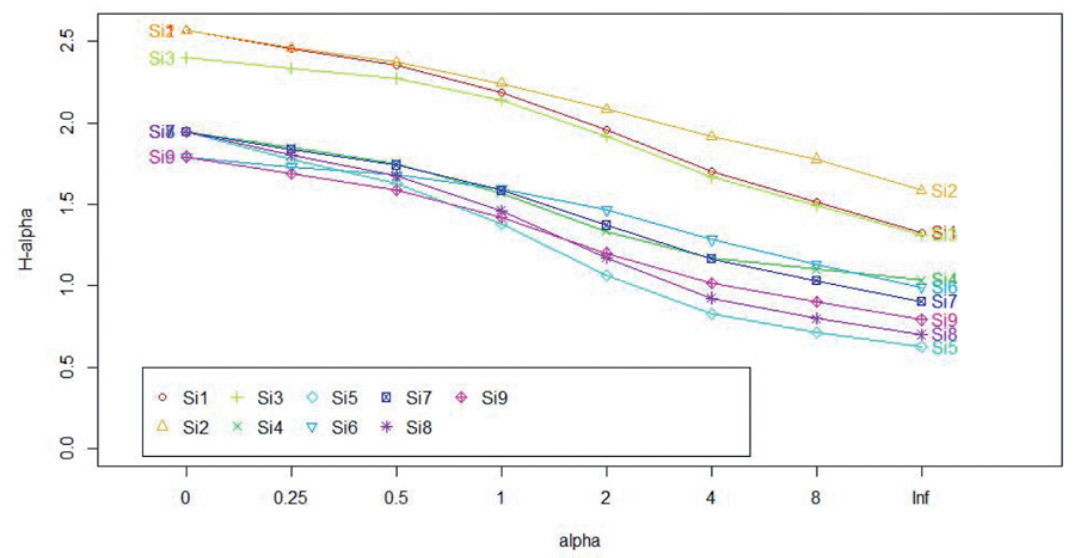

Figure 2. Rényi diversity profile of arbuscular mycorrhizal (AM) fungi per site (forest plot: Si 1 - Si 3; crater plot: Si 4 - Si 6; disturbed plot: Si 7 - Si 9). In a Rényi profile, a community A is more diverse or has more evenness than the community $\mathrm{B}$, if the former is above and never intersecting with the latter.

Sites and AM fungal species clustered based on plant available $\mathrm{P}, \mathrm{pH}$, and aluminum saturation (Sat_Al) (Figure 3). These three variables were independent (not correlated) and had different effects on structuring the AM fungal communities, as tested using the VIF criteria (Figure 3). The AM communities of the forest plot tended to be more similar than the communities of the other two plots (Figure 3). Additionally, the forest plot communities were more dependent on Sat_Al than the crater and disturbed forest communities (Figure 3). The disturbed plot sites were more de- pendent on $\mathrm{pH}$ and the crater plot sites were more dependent on plant available $\mathrm{P}$, than the other two plots, respectively. The three sites within each plot clustered as expected with species within AM fungal genera clustering well (Figure 4). Furthermore, species such as G. badium and G. invermaium were highly abundant in the crater and disturbed plot sites (lower available P) but were almost absent in the forest plot sites, which have higher Al toxicity (Figure 4). In contrast, A. laevis and A. punctate were highly abundant in the forest plot sites (Figure 4).

Table 3. Diversity indices, statistical analysis of the indices and contribution to diversity (alpha, beta and gamma diversity, Simpson's index) of AM communities in the three plots and nine sites in the Andean mountain area of south-central Chile.

\begin{tabular}{|c|c|c|c|c|c|c|c|c|c|c|}
\hline \multicolumn{2}{|l|}{ Index } & \multirow{2}{*}{$\begin{array}{l}\text { Richness } \\
\text { (S) }\end{array}$} & \multirow{2}{*}{$\begin{array}{l}\text { Shannon } \\
\left(\mathrm{H}^{\prime}\right) \\
2.132\end{array}$} & \multirow{2}{*}{$\begin{array}{l}\text { Simpson } \\
\left(1-D_{1}\right) \\
0.825\end{array}$} & \multirow{2}{*}{$\begin{array}{l}\text { Inverse } \\
\text { Simpson }\left(\mathrm{D}_{2}\right) \\
5.729\end{array}$} & \multirow{2}{*}{$\begin{array}{l}\begin{array}{l}\text { Evenness } \\
\left(\mathrm{J}^{\prime}\right)\end{array} \\
0.738\end{array}$} & \multirow{2}{*}{$\begin{array}{l}\text { Berger } \\
\text { (BP) } \\
0.304\end{array}$} & \multicolumn{3}{|c|}{ Contribution to diversity, Simpson (1-D $)$} \\
\hline All Sites & & & & & & & & Alpha & Beta & Gamma \\
\hline \multirow[t]{3}{*}{ Forest } & Si 1 & $13 \mathrm{~d}$ & $2.189 \mathrm{~d}$ & $0.859 \mathrm{~d}$ & $7.080 \mathrm{~d}$ & $0.853 \mathrm{c}$ & $0.266 a$ & $0.859 \mathrm{~d}$ & $0.038 \mathrm{a}$ & $0.897 \mathrm{~d}$ \\
\hline & Si 2 & $13 \mathrm{~d}$ & $2.242 \mathrm{~d}$ & $0.875 \mathrm{~d}$ & $8.019 \mathrm{~d}$ & $0.874 \mathrm{c}$ & $0.205 a$ & $0.875 \mathrm{~d}$ & $0.034 \mathrm{a}$ & $0.910 \mathrm{~d}$ \\
\hline & Si 3 & $11 d$ & $2.141 \mathrm{c}$ & $0.853 \mathrm{c}$ & $6.816 \mathrm{c}$ & $0.893 \mathrm{~d}$ & $0.270 \mathrm{a}$ & $0.853 \mathrm{c}$ & $0.043 \mathrm{a}$ & $0.896 \mathrm{c}$ \\
\hline \multirow[t]{3}{*}{ Crater } & Si 4 & $7 a$ & $1.570 \mathrm{~b}$ & $0.736 \mathrm{~b}$ & $3.794 b$ & $0.807 \mathrm{~b}$ & $0.355 \mathrm{~b}$ & $0.736 \mathrm{~b}$ & $0.067 \mathrm{c}$ & $0.803 \mathrm{~b}$ \\
\hline & Si 5 & $7 \mathrm{a}$ & $1.381 \mathrm{a}$ & $0.656 a$ & $2.904 a$ & $0.710 \mathrm{a}$ & $0.536 \mathrm{~d}$ & $0.656 a$ & $0.128 \mathrm{~d}$ & $0.784 a$ \\
\hline & Si 6 & $6 \mathrm{a}$ & $1.595 \mathrm{c}$ & $0.769 \mathrm{c}$ & $4.330 c$ & $0.890 \mathrm{~d}$ & $0.371 b$ & $0.769 \mathrm{c}$ & $0.057 b$ & $0.826 \mathrm{c}$ \\
\hline \multirow[t]{3}{*}{ Disturbed } & Si 7 & $7 \mathrm{a}$ & $1.586 \mathrm{~b}$ & $0.747 b$ & $3.946 \mathrm{~b}$ & $0.815 b$ & $0.405 \mathrm{c}$ & $0.747 \mathrm{~b}$ & $0.055 \mathrm{~b}$ & $0.802 \mathrm{~b}$ \\
\hline & Si 8 & $7 \mathrm{a}$ & $1.462 \mathrm{a}$ & $0.691 \mathrm{a}$ & $3.231 \mathrm{a}$ & $0.752 \mathrm{a}$ & $0.496 \mathrm{~d}$ & $0.691 \mathrm{a}$ & $0.098 \mathrm{~d}$ & $0.789 \mathrm{a}$ \\
\hline & Si 9 & $6 a$ & $1.417 \mathrm{a}$ & $0.699 a$ & $3.323 \mathrm{a}$ & $0.791 \mathrm{a}$ & $0.453 \mathrm{c}$ & $0.699 a$ & $0.084 \mathrm{c}$ & $0.783 a$ \\
\hline$F^{p}$ & & $27.307^{* *}$ & $81.264^{* *}$ & $31.885^{* *}$ & $34.922^{* *}$ & $7.107^{\mathrm{ms}}$ & $16.621^{\circ}$ & $31.885^{* *}$ & $5.569^{\mathrm{ms}}$ & $105.910^{* * *}$ \\
\hline
\end{tabular}

(a) Letters indicate quartiles. (b) Model=index plot; $F^{p}$ corresponds to the $F$ value with their respective $p$ value (p), where: Journal of Soil Science and Plant Nutrition, 2016, 16 (4), 916-929 


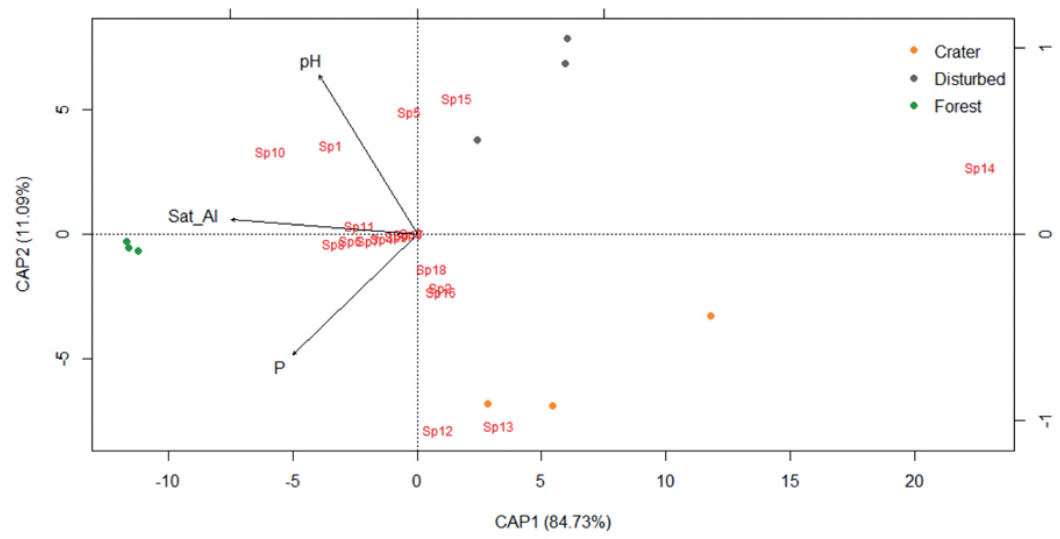

Figure 3. Distance-based Redundancy Analysis (db-RDA; Bray-Curtis dissimilarity; CAP1 explains 84.73\% of variation while CAP2 explains $11.09 \%$ ), showing the effect of the edaphic variables measured in clustering the nine sites (forest plot: Si 1 - Si 3; crater plot: Si 4 - Si 6; disturbed plot: Si 7 - Si 9), and the 18 described species of arbuscular mycorrhizal (AM) fungi. Permutation test for db-RDA (1000 permutations; model: $\sim \mathrm{pH}+\mathrm{P}+$ Sat_Al; variables selected due to VIF regression, threshold $=10$ ): pseudo $\mathrm{F}$ value: 10.846; significance: 0.002. Species legend: Sp1: Acaulospora alpina, Sp2: Acaulospora laevis, Sp3: Acaulospora myriocarpa, Sp4: Acaulospora paulinae, Sp5: Acaulospora punctata, Sp6: Acaulosporas crobiculata, Sp7: Acaulospora sp CL1, Sp8: Acaulospora sp CL2, Sp9: Acaulospora spinosa, Sp10: Ambispora reticulata, Sp11: Archaeospora trappei, Sp12: Claroideoglomus claroideum, Sp13: Claroideoglomus etunicatum, Sp14: Glomus badium, Sp15: Glomus invermaium, Sp16: Rhizoglomus intraradices, Sp17: Scutellospora calospora, Sp18: Simiglomus hoi.

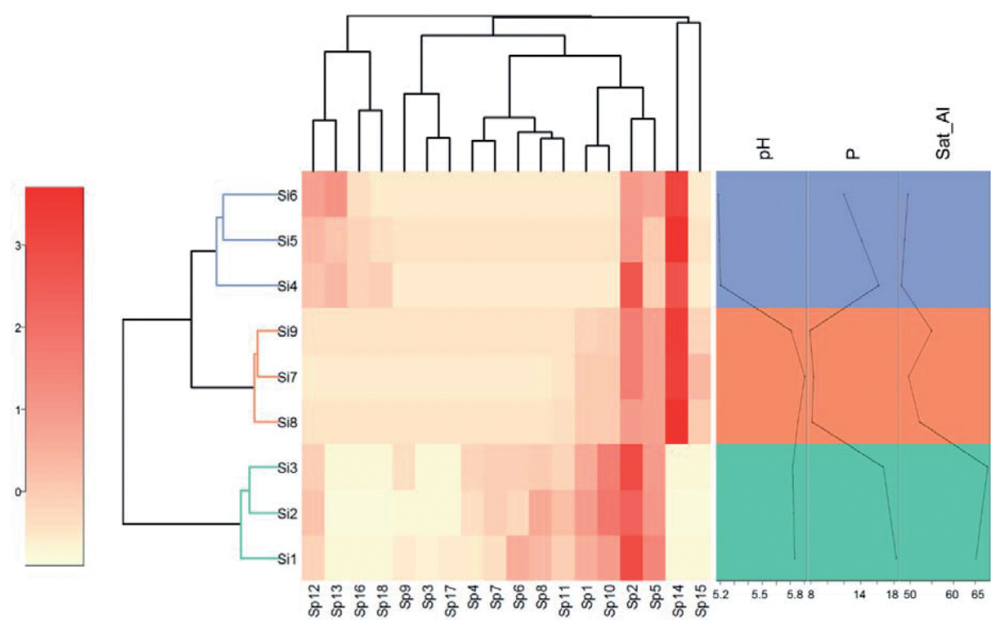

Figure 4. Heatmap and clustering (Bray-Curtis dissimilarity) for the 18 arbuscular mycorrhizal (AM) fungi species described in the three studied plots (forest plot: Si 1-Si 3, green; crater plot: Si 4 - Si 6, orange; disturbed plot: Si 7 - Si 9, blue), showing the edaphic variables which significantly structure the AM fungi communities. Species legend: Sp1: Acaulospora alpina, Sp2: Acaulospora laevis, Sp3: Acaulospora myriocarpa, Sp4: Acaulospora paulinae, Sp5: Acaulospora punctata, Sp6: Acaulosporas crobiculata, Sp7: Acaulospora spCL1, Sp8: Acaulospora spCL2, Sp9: Acaulospora spinosa, Sp10: Ambispora reticulata, Sp11: Archaeospora trappei, Sp12: Claroideoglomus claroideum, Sp13: Claroideoglomus etunicatum, Sp14: Glomus badium, Sp15: Glomus invermaium, Sp16: Rhizoglomus intraradices, Sp17: Scutellospora calospora, Sp18: Simiglomus hoi. 


\section{Discussion}

The diversity and abundance of soil fungal groups, including mycorrhizal fungi, is dependent on nutrient availability on soil and plants (Tedersoo et al., 2014) as well on plant assemblages and patterns. At the global scale, $\mathrm{pH}, \mathrm{P}$, and $\mathrm{Ca}$ are the main edaphic variables structuring soil fungal assemblages (Tedersoo et al., 2014). At a local scale, in our study, pH, $\mathrm{P}$ and Sat_Al were important edaphic factors structuring AM fungal assemblages (Figure 3). Samples taken from the non-disturbed plot (forest) were highly similar in their assemblages, compared to samples taken from human and naturally disturbed plots (disturbed forest and crater, respectively; Figure 3). It is important to note that the forest plot sites had higher alpha diversity and evenness (Figure 2; also reflected in Table 3 with several diversity indices) than the sites from the other two plots. Alpha diversity constitutes an important component of gamma diversity in the nine sites (Table 3), which is concordant with low species turnover (low beta diversity), meaning that a few species were different in the studied plots and sites (Figure 4).

Among those differentiating species, interestingly, the AM Glomus species (G. badium and G. invermaium) were absent in the non-disturbed forest plot, but were highly abundant in the lower-diversity and lower-evenness, disturbed plots (disturbed forest and crater; Table 2, Figure 4). Thus, it could be predicted that Glomus spp. are potential successional pioneers in disturbed habitats (either human or naturally disturbed), especially in conditions of nutrient limitation (Table 1, Figure 4). Acaulospora species have an important role allowing plants to adapt to highly acidic and Al-saturated environments (Aguilera et al., 2014). This is accomplished by Al immobilization in fungal propagules (Aguilera et al., 2014). In our study, A. laevis and A. punctata were highly abundant in soils with $\mathrm{Al}$ occupying most of the exchangeable sites, as indicated by percentage of Al saturation close to $70 \%$ (forest plot sites; Table 1, Figure 4). This is typical from temperate rainforests acidic soils, since $\mathrm{Al}$ is able to replace cations such as $\mathrm{Mg}$ and $\mathrm{Ca}$ from exchangeable sites, which are removed from the soil profile (Soil Survey Staff, 1999). Remarkably, the forest plot sites had higher levels of Al (Table 1, Figure 4) and the fungal communities may be highly influenced by Al saturation (Figure 3). The forest plot sites also had the highest AM richness (Table 3) and evenness (Figure 2), and they also had higher plant available P (Table 1, Figure 4).

In line with Turner (2008) P-niche partitioning hypothesis, even at general low plant available P, AM fungi species were detected that specialize at the lower plant available P levels (Figure 4). The high predominance and diversity of AM fungi (Figure 4) in these high-altitude, mountainous conditions is comparable to lowland AM fungal diversity (Carrillo et al., 1992); thus, this may be a signal of the importance of AM fungal 'services' to plants in adverse habitats (Oehl et al., 2012).

\section{Conclusions}

This study is one of the first morphological identification studies of AM in a typical Andean treeline forest ecosystem (Nothofagus pumilio) with a broad latitudinal distribution ( $>2,000 \mathrm{~km})$; thus, this study could serve as a basis for further identification studies. Molecular methods are definitely needed to further identify soil biota and to provide a complementary view of the diversity of this ecosystem.

More studies of soil biota, and specifically of mycorrhizal associations across altitudinal gradients, are needed in order to better understand the plant and associated soil biota community responses to changing biogeochemical cycles (due to rising temperature and 
$\mathrm{CO}_{2}$ and droughts currently happening in Southern Chile). Future studies exploring the role of mycorrhizae in C, N, P and SOM biogeochemical cycles (by nutrient recycling and biogenic weathering) would further elucidate the ecological role of mycorrhizae in Chilean temperate rainforests.

\section{Acknowledments}

We thank Maarja Öpik and Emily Giles for their helpful comments regarding this manuscript. This study was partially funded by the CONICYT National Doctorate Scholarship No. 21150047, and by the FONDECYT projects No. 1141060 and No. 3150175.

\section{References}

Aguilera, P., Cornejo, P., Borie, F., Barea, J.M., Von Baer, E., Oehl, F. 2014.Diversity of arbuscular mycorrhizal fungi associated with Triticumaestivum L. plants growing in an Andosol with high aluminum level. Agr.Ecosyst.Environ. 186, 178184.

Álvarez, C.,Veblen, T.T., Christie, D.A., GonzálezReyes, A. 2015. Relationships between climate variability and radial growth of Nothofaguspumilio near altitudinal treeline in the Andes of northern Patagonia, Chile. Forest Ecol. Manag.342, 112-121.

Armesto, J.J., Manuschevich, D., Mora, A., SmithRamirez, C., Rozzi, R., Abarzúa, A.M., Marquet, P.A. 2010. From the holocene to the Anthropocene: A historical framework for land cover change in southwestern South America in the past 15,000 years. Land Use Policy. 27, 148-160.

Azcón-Aguilar, C., Barea, J.M. 2015. Nutrient cycling in the mycorrhizosphere. J. Soil Sci. Plant Nutr. 25, 372-396.
Borie, F., Rubio, R., Morales, A., Curaqueo, G., Cornejo, P.2010. Arbuscular mycorrhizae in agricultural and forest ecosystems in Chile. J. Soil Sci. Plant Nutr. 10, 185-206.

Briceño, V.F., Harris-Pascal, D., Nicotra, A.B., Williams, E., Ball, M.C. 2014. Variation in snow cover drives differences in frost resistance in seedlings of the alpine herb Aciphyllaglacialis. Environ. Exp. Bot. 106, 174-181.

Carrillo, R., Godoy, R., Peredo, H. 1992. Simbiosis micorrízica en comunidades boscosas del valle Central en el Sur de Chile. Bosque. 13, 57-67.

Castillo, C.G., Borie, F., Godoy, R., Rubio, R., Sieverding, E. 2006. Diversity of mycorrhizal plant species and arbuscularmycorrhizal fungi in evergreen forest, deciduous forest and grassland ecosystems of Southern Chile. J. Appl. Bot. Food Qual. 80, 40-47.

Castillo, C.G., Borie, F., Oehl, F., Sieverding, E. 2016. Arbuscular mycorrhizal fungi biodiversity: prospecting in Southern-Central zone of Chile. A review. J. Soil Sci. Plant Nutr. 16, 400-422.

Davison, J., Moora, M., Öpik, M., Adholeya, A., Ainsaar, L., Bâ, A., Burla, S., Diedhiou, A.G., Hiiesalu, I., Jairus, T., Johnson, N.C., Kane, A., Koorem, K., Kochar, M., Ndiaye, C., Pärtel, M., Reier, Ü., Saks, Ü., Singh, R., Vasar, M., Zobel, M. 2015. Global assessment of arbuscular mycorrhizal fungus diversity reveals very low endemism. Science. 349, 970-973.

Etcheverría, P., Huygens, D., Godoy, R., Borie, F., Boeckx, P. 2009. Arbuscular mycorrhizal fungi contribute to ${ }_{13} \mathrm{C}$ and ${ }_{15} \mathrm{~N}$ enrichment of soil organic matter in forest soils. Soil. Biol. Biochem. $41,858-861$.

Freiberg,H.-M.1985.VegetationskundlicheUntersuchungenan südchilenischen Vulkanen.Bonner Geographische Abhandlungen. 70, 1-170. 
Godoy, R., Mayr, R. 1989. Caracterización morfológica de micorrizas vesículo-arbusculares en coníferas endémicas del sur de Chile. Bosque. 10, 89-98.

Godoy, R., Opitz, G. 1998. Estudios de distribución de biomasa radical en bosques de Nothofagus pumilio. Noticiero de Biología (Chile). 6, 114115.

Godoy, R., Romero, R., Carrillo, R. 1994. Estatus micotrófico de la flora vascular en bosques de coníferas nativas. Rev. Chil. Hist. Nat. 67, 209220.

Kindt, R., Coe, R. 2005. Tree diversity analysis: a manual and software for common statistical methods for ecological and biodiversity studies. World Agroforestry Centre, Nairobi, 196 p.

Matus, F., Panichini, M., Godoy, R., Borie, F. 2009. Soil carbon storage in allophanic soils: Study of a pristine Nothofagus pumilio in the upper altitudinal limit of temperate rain forest. In: N. Verhoest, P. Boeckx, C. Oyarzún, R. Godoy (eds). Ecological advances on Chilean temperate rainforests. Academia Press, Ghent, pp:147-170.

Matus, F., Rumpel, C., Neculman, R., Panichini, M., Mora, M.L. 2014. Soil carbon storage and stabilisation in andic soils: a review. Catena, 120, 102110.

Medina, J., Meier, S., Rubio, R., Curaqueo, G., Borie, F., Aguilera, P., Oehl, F., Cornejo, P. 2015. Arbuscular mycorrhizal status of pioneer plants from the mouth of lake Budi, Araucanía Region, Chile. J. Soil Sci. Plant Nutr. 15, 142-152.

Nouhra, E., Urcelay, C., Longo, S.,Tedersoo, L. 2013. Ectomycorrhizal fungal communitiesa ssociated to Nothofagus species in northern Patagonia. Mycorrhiza. 23, 487-496.

Oehl, F., Sieverding, E., Palenzuela, J., Ineichen, K., Da Silva, G.A. 2011a. Advances in Glomeromy- cota taxonomy and classification. IMA Fungus, 2, 191-199.

Oehl, F., Da Silva,A.G., Goto, B.T., Costa Maia, L., Sieverding, E. 2011b. Glomeromycota: two new classes and a new order. Mycotaxon. 116, 365379 .

Oehl, F., Castillo, C., Schneider, D., Säle, V., Sieverding, E. 2012. Ambispora reticulata, a new species in the Glomeromycota from mountainous areas in Switzerland and Chile. J. Appl. Bot. Food Qual. 85, 129-133.

Oksanen, J., Blanchet, F.G., Kindt, R., Legendre, P., Minchin, P.R., O’Hara, R.B., Simpson, G.L., Solymos, P., Stevens, M.H.H., Wagner, H. 2015. Vegan: Community Ecology Package. R packageversion 2.3-1. http://CRAN.R-project.org/package $=$ vegan

Oyarzún, C.E., Godoy, R., De Schrijver, A., Staelens, J.,Lust, N. 2004. Water chemistry and nutrient budgets in an undisturbed evergreen rainforest of southern Chile. Biogeochemistry. 71, 107-123.

R Development Core Team. 2015. R: A Language and Environment for Statistical Computing. The R Foundation for Statistical Computing, Vienna. Available: http://www.R-project.org/

Seguel, A., Castillo, C.G., Morales, A., Campos, P., Cornejo, P., Borie, F. 2016. Arbuscular Mycorrhizal symbiosis in four Al-tolerant wheat genotypes grown in an acidic Andisol. J. Soil Sci. Plant Nutr. $16,164-173$

Sieverding, E. 1991. Vesicular-arbuscular Mycorrhiza Management in Tropical Agrosystems. GTZ, Eschborn, $371 \mathrm{p}$.

Soil Survey Staff. 1999. Soil Taxonomy. A basic system of soil classification for making and interpreting soil surveys, 2nd edition. Agricultural Handbook 436, Natural Resources Conservation Service, USDA, Washington D.C., 869 p. 
Soudzilovskaia, N.A., Douma, J.C., Akhmetzhanova, A.A., Bodegom, P.M., Cornwell, W.K., Moens, E.J., Treseder, K.K., Tibbett, M., Wang, Y.-P., Cornelissen, J.H.C. 2015. Global patterns of plant root colonization intensity by mycorrhizal fungi explained by climate and soil chemistry. Global Ecol. Biogeogr. 24, 371-382.

Tedersoo, L., Bahram, M., Põlme, S., Kõljalg, U., Yorou, N.S., Wijesundera, R., Ruiz, L.V., VascoPalacios, A.M., Quang Thu, P., Suija, A., Smith, M.E., Sharp, C., Saluveer, E., Saitta, A., Rosas, M., Riit, T., Ratkowsky, D., Pritsch, K., Põldmaa, K., Piepenbring, M., Phosri, C., Peterson, M., Parts, K., Pärtel, K., Otsing, E., Nouhra, E., Njouonkou, A.L., Nilsson, R.H., Morgado, L.N., Mayor, J., May, T.W., Majuakim, L., Lodge, D.J., Lee, S.S., Larsson, K.-H., Kohout, P., Hosaka, K., Hiiesalu, I., Henkel, T.W., Harend, H., Guo, L., Greslebin, A., Grelet, G., Geml, J., Gates, G., Dunstan, W., Dunk, C., Drenkhan, R., Dearnaley, J., De Kesel, A., Dang, T., Chen, X., Buegger, F.,
Brearley, F.Q., Bonito, G., Anslan, S., Abell, S., Abarenkov, K. 2014. Global diversity and geography of soil fungi. Science, 346, 1256688.

Turner, B.L. 2008. Resource partitioning for soilphosphorus: ahypothesis. Journal Ecol. 96, 698-702.

Valenzuela, E., Moreno, G., Garnica, S., Godoy, R., Ramírez, C. 1999. Mycosociology in native forests of Nothofagus of the X Región of Chile, diversity and ecological role. Mycotaxon, 72, 217226.

Zagal, E., Sadzawka, A. 2007. Protocolo de métodos de análisis para suelos y lodos. Universidad de Concepción, Servicio Agrícola y Ganadero, Santiago, $103 \mathrm{p}$. 